\title{
Tsunami design procedures for engineered buildings: a critical review
}

Joshua Macabuag EngD, CEng, MICE

Natural Catastrophe Analyst, R\&D, SCOR, London, UK; formerly

Engineering Doctorate candidate, EPICentre, University College London, London, UK (corresponding author: macabuag@gmail.com)

Alison Raby PhD, DPhil

Associate Professor of Coastal Engineering, School of Engineering, University of Plymouth, Plymouth, UK

Antonios Pomonis MSC

Director, Cambridge Architectural Research Limited, Cambridge, UK
Ioan Nistor PhD

Professor of Hydraulic and Coastal Engineering, Department of Civil Engineering, University of Ottawa, Ottawa, Canada

Sean Wilkinson PhD

Reader in Structural Engineering, School of Civil Engineering and

Geosciences, Newcastle University, Newcastle, UK

Tiziana Rossetto PhD

Director, EPICentre, University College London, London, UK

Tsunamis have the potential to cause enormous loss of life and socio-economic impacts on coastal communities. Central to tsunami risk mitigation is the protection of critical infrastructure and evacuation-designated buildings, which are often necessarily located within tsunami inundation zones. As such, these must be designed to withstand and remain fully or partially operational after a tsunami. Guidance documents for tsunami design of buildings exist in the USA and Japan, including the recent release of the US ASCE 7 chapter 6 on tsunami loads and effects. This paper outlines the key engineering principles of tsunami design of buildings, summarises and compares how these principles are addressed by US and Japanese standards, and outlines considerations not yet covered.

\section{Introduction}

The vast majority of tsunamis (Figure 1) are usually triggered by earthquakes in oceanic or other marine subduction zones. They are caused by submarine landslides and volcanic flank collapse during major eruptions and, as such, there is tsunami risk in many parts of the globe (Figure 2; NGDC NOAA (2013)).

Disaster managers and coastal planners designate buildings which must be designed to be both tall enough for people in the tsunami hazard zone to evacuate to a level above the inundation depth, and strong enough so that they do not experience structural failure under the forces induced by the tsunami. The design and provision of such buildings varies greatly by country.

On 11 March 2011, a magnitude 9.0 earthquake generated tsunami waves that seriously affected approximately $650 \mathrm{~km}$ of the Pacific Ocean coast of north-east Japan. The Great East Japan Earthquake and Tsunami (GEJE) toppled sea defences, inundated more than $500 \mathrm{~km}^{2}$ of nearshore land, severely damaged critical infrastructure and buildings (such as vertical evacuation structures, schools, municipal administration buildings and hospitals),

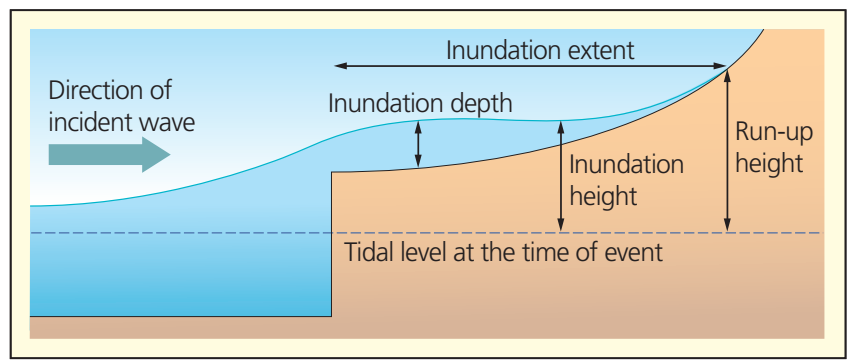

Figure 1. Definition of tsunami terminology (adapted from Fraser et al. (2012)) triggered the nuclear crisis at the Fukushima Daiichi nuclear power plant, and is thought to have cost nearly 18500 lives (NPAJ, 2017).

Data from the GEJE and recent research have led to updated Japanese guidelines. More importantly, the 2016 edition of the ASCE 7 code 'Minimum Design Loads and Associated Criteria for Buildings and Other Structures' (ASCE, 2016) includes a newly developed chapter 6 entitled 'Tsunami loads and effects', which presents the world's first tsunami design code written in mandatory language. A limited number of other countries are deriving local guidelines based on these, such as Chile.

Notably, despite the fact that a risk and precedent of large tsunamis exists around some European coastal regions including parts of the UK (McCabe et al., 2014), European design codes of practice do not address tsunami loading. The same is true of many other at-risk locations around the world, including the Pacific 'ring of fire', the Indian Ocean, the Mediterranean Sea, the North Sea and certain regions of the Black and Marmara Seas.

This paper summarises field observations made by the Earthquake Engineering Field Investigation Team (EEFIT) - a UK-based group of earthquake engineers, architects and scientists - following the GEJE regarding building damage and failure mechanisms. It then presents and contrasts tsunami design guidance documents from Japan and the USA, discussing the underlying assumptions behind the development of the current approaches, and draws attention to a number of design conditions not yet covered by design standards.

A loading example is used to quantify and compare the design loads from the USA and Japanese design standards. Note that for brevity only lateral fluid forces are considered, with debris and foundation instability effects due to scouring being ignored. Debris loading represents a significant component of the design considerations for tsunami-resistant structures (Chock, 2016; Nistor et al., 2017). However, in the context of the analysis of the currently available design recommendations and standards, the main focus of the present analysis is related to the hydrodynamic 


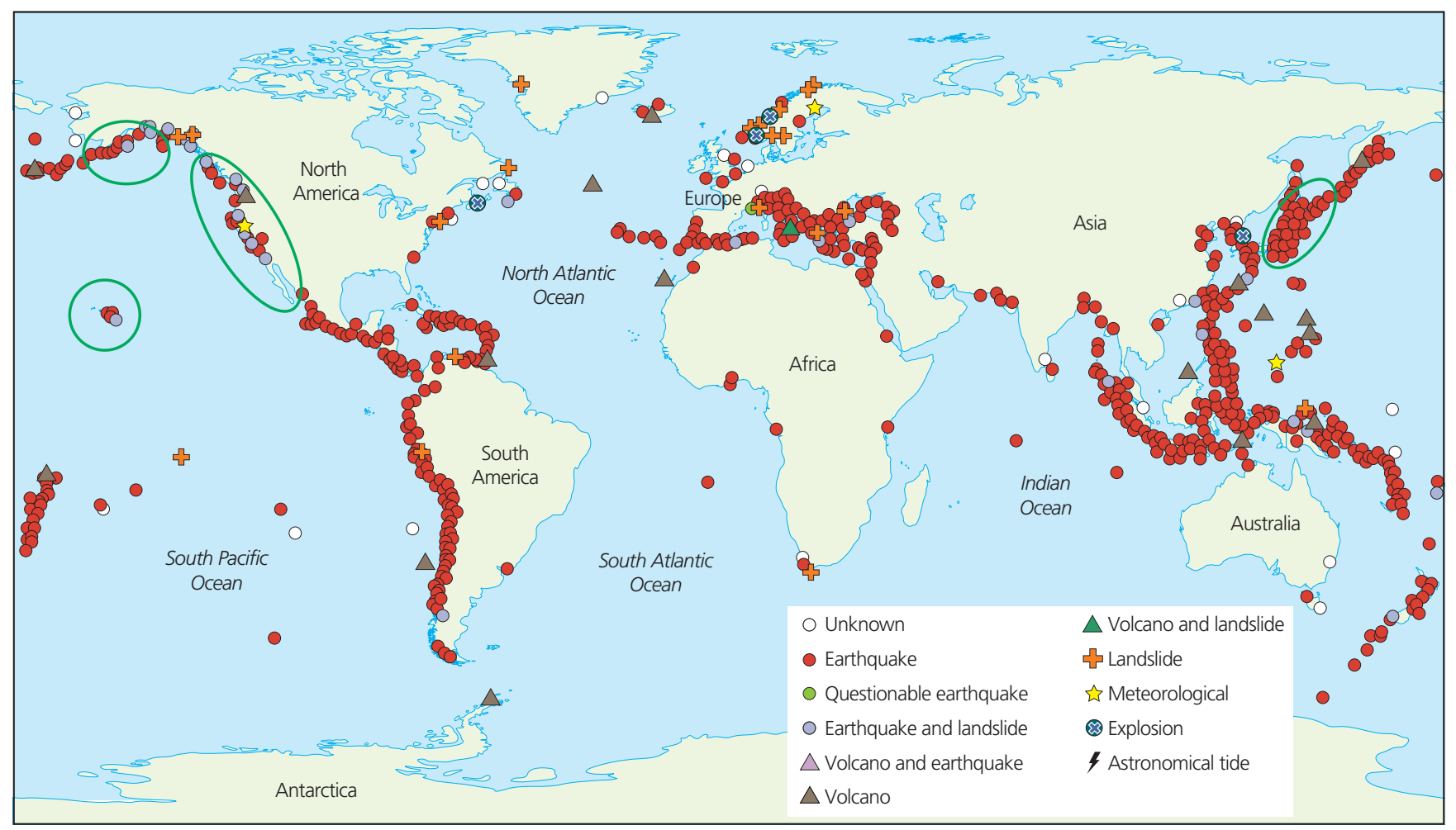

Figure 2. Historical tsunami events - locations currently with tsunami design guidance documents ringed in green (adapted from Nassirpour (2012))

component of tsunami-induced loading. Additionally, foundation instabilities are directly related to the hydrodynamics of the tsunami inundation.

The purpose is not to replicate information already provided in design guidance documents but to

- provide practising engineers with an understanding of the range of design cases for which current guidance is applicable

- inform those responsible for the development of design standards where guidance is required and outline the current state of the art on the subject

- highlight to practising engineers and researchers conditions not yet covered in design standards, which will require special consideration during design and research.

This paper specifically addresses the engineering design of critical infrastructure and evacuation buildings, with many of the principles also applying more generally to other forms of construction, such as sea defences (Raby et al., 2015).

\section{The 2011 Great East Japan Earthquake and Tsunami}

Tsunami-induced loading is very difficult to recreate experimentally at an adequate spatial and temporal scale (Arikawa et al., 2012; Foster et al., 2017; Robertson et al.,
2011; Rossetto et al., 2011). The GEJE has provided the only opportunity fully to investigate tsunami-induced loads, effects and failure mechanisms on engineered structures (Chock et al., 2013; EEFIT, 2011, 2013).

To learn and disseminate key lessons from the event, EEFIT conducted two missions to Japan. Table 1 outlines the various loads and effects observed on engineered buildings which must be considered to quantify tsunami-induced demand on buildings. Table 2 shows a categorisation of observed damage patterns and failure mechanisms, which must be considered when designing or checking structural capacity, recognising that failure may occur due to a combination of these loads, effects and mechanisms.

The potential damage mechanisms can be mitigated by designing elements such that structural capacity exceeds demand, or by reducing the demand through alternative measures (Figure 3). Tsunami-resistant design must also occur with consideration of alternative hazards, to ensure holistically appropriate structural response - for example, increasing member capacity and stiffness may be detrimental to dynamic response under seismic loading (Figure 4).

\section{Comparison of design approach}

The design approaches presented in current Japanese guidance (MLIT 2570 (MLIT, 2011b)) and USA guidance (ASCE 7-16 (ASCE, 2016) chapter 6) are compared in Table 3 and expanded on below. 
Table 1. Tsunami loads and effects observed during GEJE showing (a) Minami Gamou wastewater treatment plant, where reinforced concrete walls have been deformed primarily by hydrostatic pressure (analysed by Robertson et al. (2013)); (b) residual deformation of a reinforced concrete building; (c) evidence of a large debris impact on the top floor of overturned reinforced-concrete-frame building in Onagawa (collapse likely due to combination of drag, buoyancy, debris and seismic damage); (d) openings dammed in Shichigahama by debris; and (e) and (f) foundations undermined by scour at Arahama, Sendai and Onagawa, respectively (EEFIT (2011), characterisation consistent with ASCE 7-16 (ASCE, 2016))
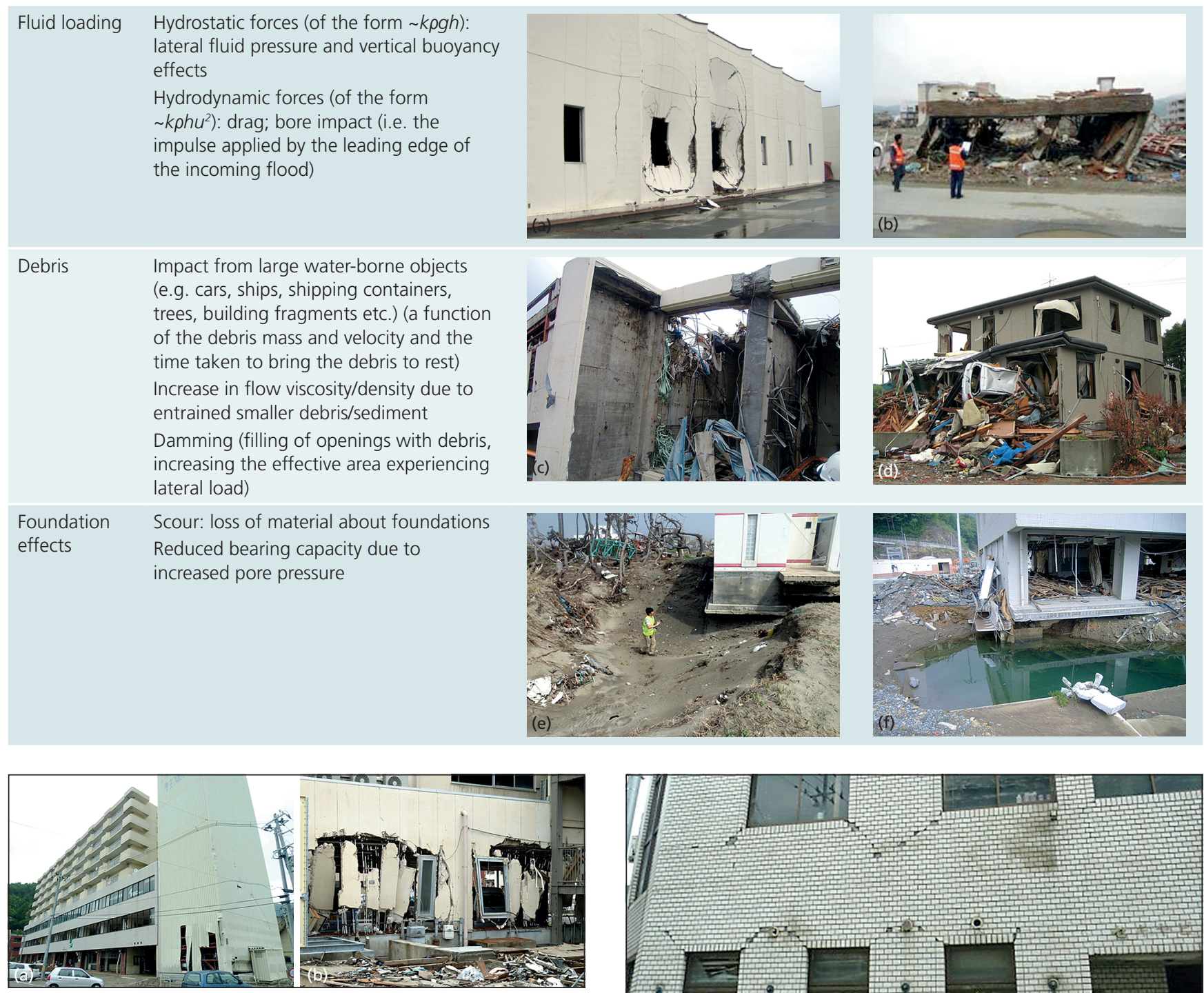

Figure 3. A steel-framed vertical car park on the seaward side of this retail and residential building in Kamaishi shielded the main structure from large debris (a), failed cladding panels on the seaward side of the open-plan ground floor (b)

\subsection{Design guidance in Japan}

\subsubsection{Building design procedure}

MLIT 2570 (MLIT, 2011a, 2011b), provides provisional amendments to the Japan Cabinet Office (2005) Tsunami Evacuation Building Guidelines. The National Institute for Land and Infrastructure Management (NILIM) and Japan's Building Research Institute (BRI) have continued to develop more detailed guidance recommendations for design of tsunami evacuation structures (Figure 5). These documents are mainly targeted at the design of evacuation structures. Generally, verification of structural

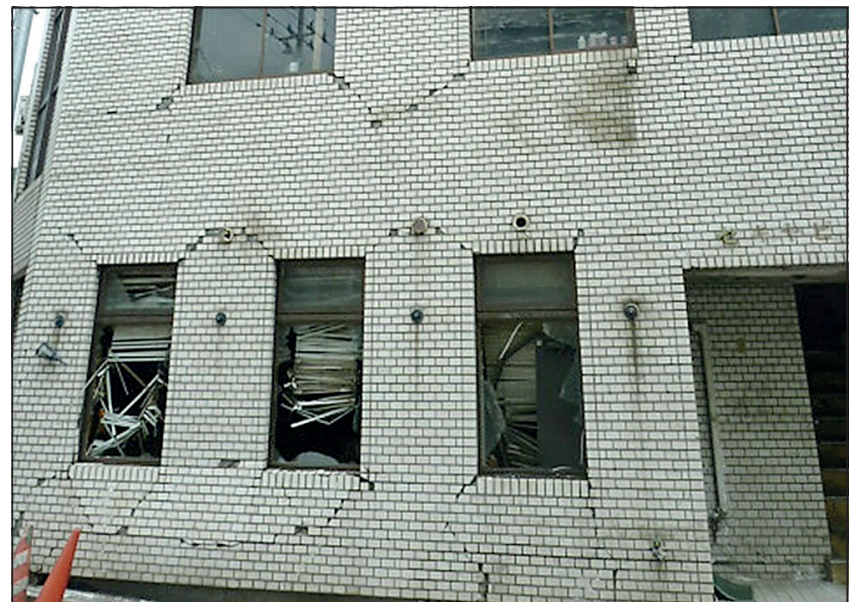

Figure 4. Tsunami-preceding seismic damage indicated by conjugate shear cracking of a building facade in Kamaishi

safety against tsunami loading is not prescribed (EEFIT, 2013) in the Building Standard Law of Japan (BSLJ) (Hitomitsu, 2011), except for buildings within local government-designated 'high-risk areas' under BSLJ article 39 (Table 4). 
Civil Engineering

Volume 171 Issue CE4
Tsunami design procedures for engineered

buildings: a critical review

Macabuag, Raby, Pomonis et al.

Table 2. Tsunami-induced damage and failure mechanisms observed during GEJE (EEFIT, 2011)

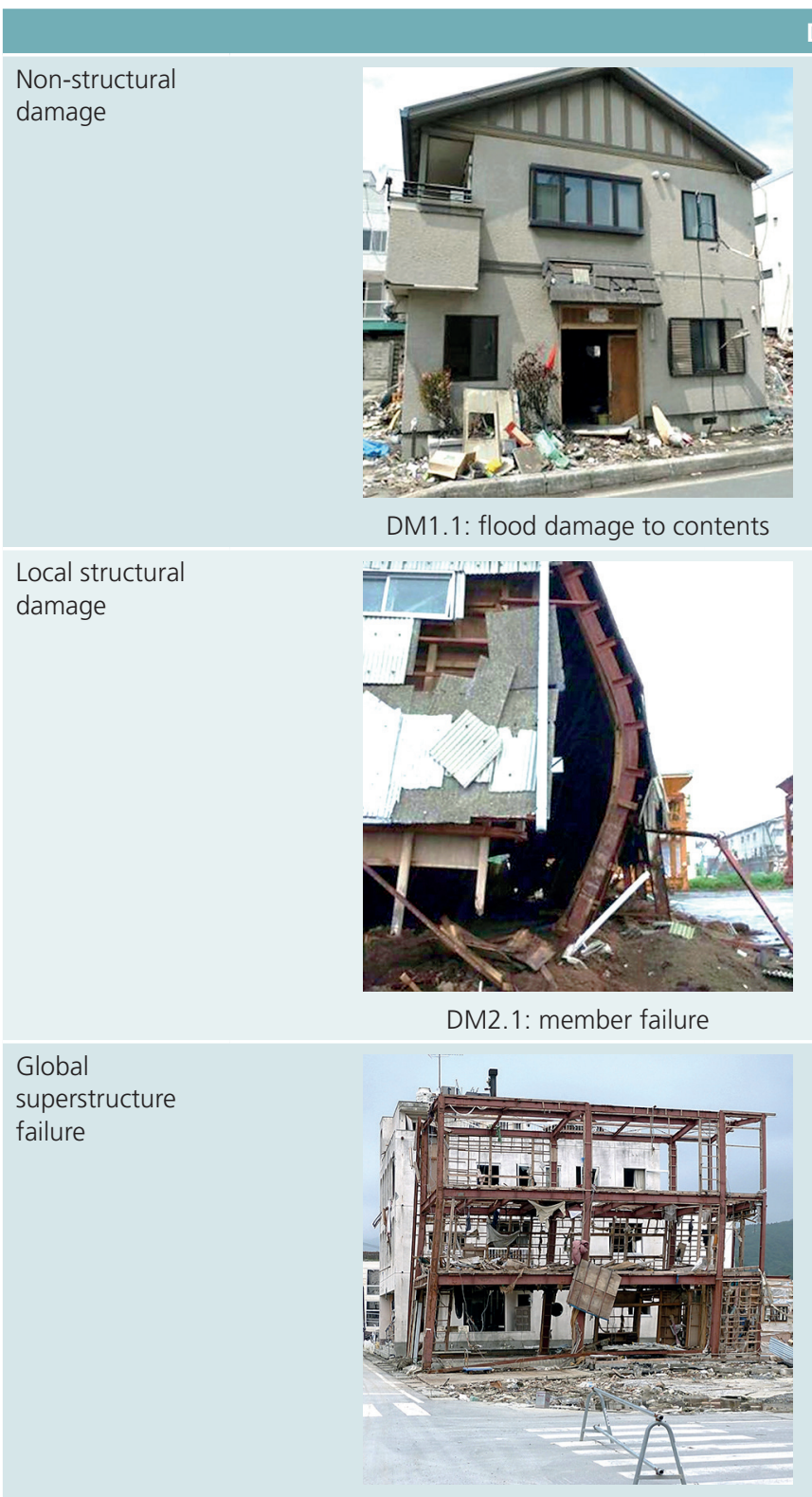

DM3.1: global lateral deflection/failure

Foundation

failure

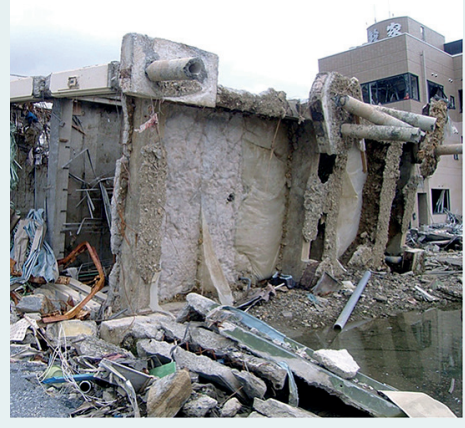

DM4.1: overturning

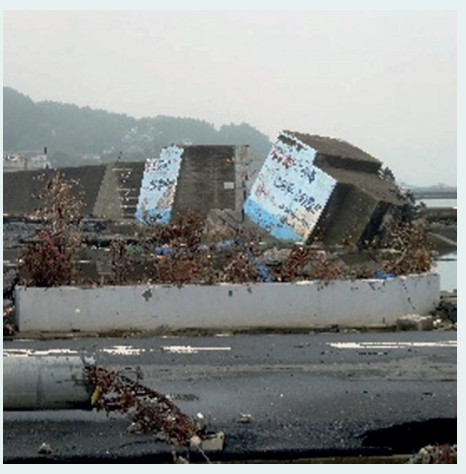

DM4.2: sliding

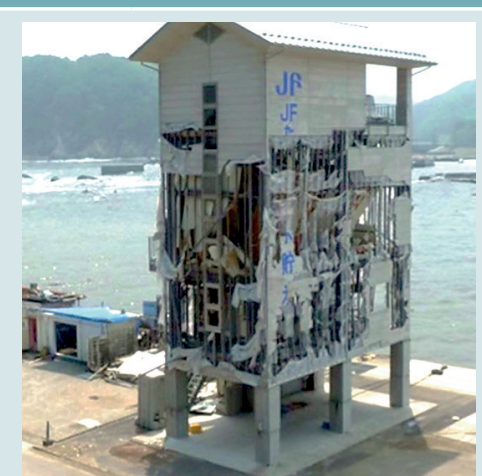

DM1.2: damage to cladding/finishes

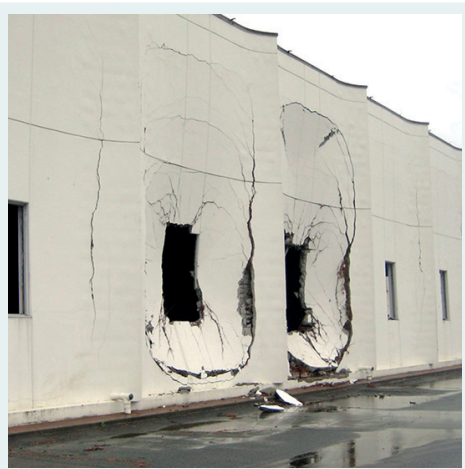

DM2.2: load-bearing wall failure

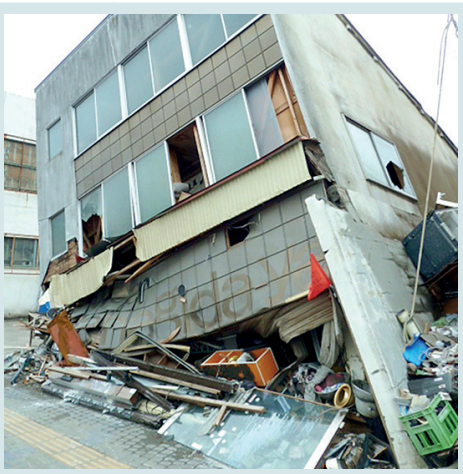

DM3.2: progressive collapse

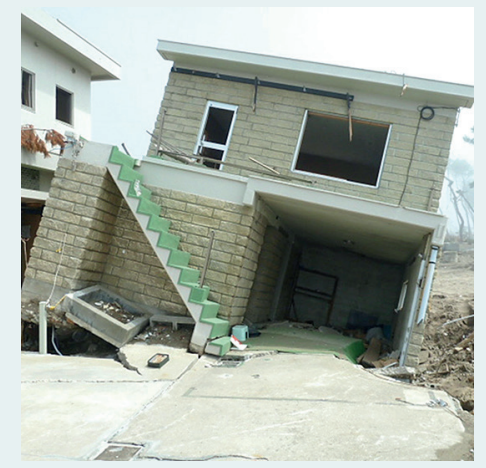

DM4.3: bearing failure 
Table 3. Comparison of key features in tsunami design guidance documents

\begin{tabular}{|c|c|c|}
\hline & Japanese guidance: MLIT 2570 (MLIT, 2011b) & US guidance: ASCE 7-16 (ASCE, 2016: ch. 6) \\
\hline $\begin{array}{l}\text { Tsunami } \\
\text { hazard } \\
\text { assessment }\end{array}$ & $\begin{array}{l}\text { Tsunami inundation maps are defined from deterministic } \\
\text { tsunami hazard assessments based on source earthquakes } \\
\text { with two approximate return periods: level 1, 1-in-100 years; } \\
\text { level 2, 1-in-1000 years. }\end{array}$ & $\begin{array}{l}\text { Offshore tsunami wave amplitude maps are calculated and } \\
\text { provided at the bathymetry contour of } 100 \mathrm{~m} \text { depth, determined } \\
\text { from probabilistic tsunami hazard assessment (carried out for } \\
\text { five states in the USA, which are deemed to have the greatest } \\
\text { tsunami risk: Alaska, Hawaii, Washington, Oregon and California). } \\
\text { The maximum considered tsunami corresponds to a } 1 \text {-in- } 2475- \\
\text { year event which represents a } 2 \% \text { probability of being exceeded } \\
\text { in a } 50 \text {-year period. }\end{array}$ \\
\hline $\begin{array}{l}\text { Sea defence } \\
\text { design }\end{array}$ & $\begin{array}{l}\text { Sea defence design guidance is developed by the Japan } \\
\text { Society of Civil Engineers and other institutions in Japan. } \\
\text { The design procedure is to prevent inundation from a level } 1 \\
\text { event, and prevent structural failure (but allow overtopping) } \\
\text { for a level } 2 \text { event (Raby et al., 2015). }\end{array}$ & $\begin{array}{l}\text { There is currently no accepted code of practice which specifically } \\
\text { addresses tsunami design of sea defences in the USA except } \\
\text { for design guidelines such as CCH-2000 (CCH, 2000) or FEMA } \\
\text { P646-2012 (FEMA, 2012). }\end{array}$ \\
\hline $\begin{array}{l}\text { Building } \\
\text { design } \\
\text { procedure }\end{array}$ & $\begin{array}{l}\text { Buildings designated to withstand tsunami loading are designed } \\
\text { for inundation corresponding to a level } 2 \text { event (as inundation } \\
\text { due to a level } 1 \text { event should be prevented by sea defences). } \\
\text { Member and structure design needs to account for lateral } \\
\text { fluid loads, buoyancy, retained water and secondary effects } \\
\text { of debris impact (by prevention of progressive collapse) and } \\
\text { scour (by use of deep foundations), though little guidance is } \\
\text { provided for the quantification of these secondary effects. }\end{array}$ & $\begin{array}{l}\text { Performance-based design using tsunami risk categories and } \\
\text { performance level objectives based on building function and } \\
\text { occupancy. } \\
\text { Member and structure design needs to account for lateral } \\
\text { fluid loads, buoyancy, retained water, and secondary effects of } \\
\text { debris impact and scour. Guidance is given on quantification of } \\
\text { secondary effects of debris impact and estimated scour depth. }\end{array}$ \\
\hline $\begin{array}{l}\text { Load } \\
\text { assessment } \\
\text { for buildings }\end{array}$ & $\begin{array}{l}\text { Lateral fluid load is calculated as an equivalent hydrostatic } \\
\text { load applied to one side of the structure. Height of } \\
\text { hydrostatic load profile is taken as the design inundation } \\
\text { depth multiplied by a factor which accounts for distance } \\
\text { from shore and presence/absence of seaward obstacles. } \\
\text { Calculations require a design inundation depth, which may } \\
\text { be taken directly from tsunami inundation maps, provided } \\
\text { by coastal municipalities. }\end{array}$ & $\begin{array}{l}\text { Lateral fluid load is calculated for hydrostatic and hydrodynamic } \\
\text { force components using calculated inundation depths and } \\
\text { velocities. } \\
\text { Calculations require design inundation depth and velocity, which } \\
\text { are calculated from publicly available offshore tsunami amplitude } \\
\text { maps, using either the energy grade line analysis or site-specific } \\
\text { numerical inundation modelling. }\end{array}$ \\
\hline
\end{tabular}

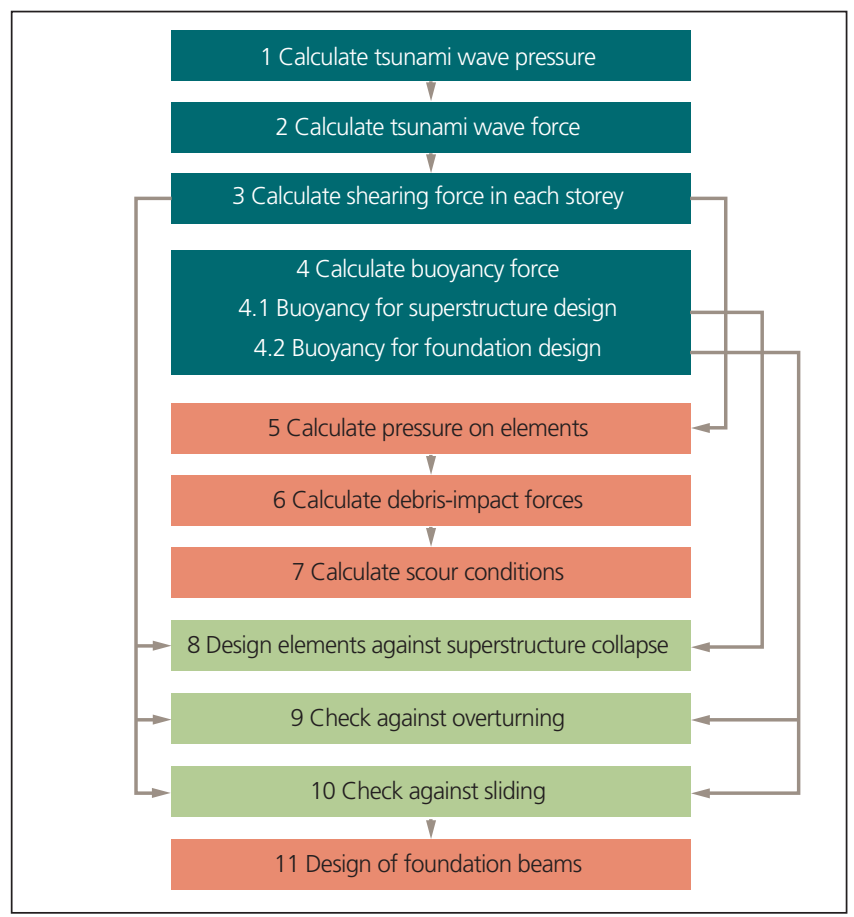

Figure 5. Japanese design framework for tsunami evacuation buildings (adapted from Fukuyama et al. (2012))
It is proposed that wave loading be reduced in proportion to the structure's openings (e.g. doors and windows) on the pressureexposed side, but by no more than $30 \%$. Guidance is provided on the calculation of buoyancy for foundation and superstructure design. Debris and scour are also to be considered, as shown in Figure 5, though quantification of these effects is not explicitly provided. For debris impact, it is recommended that progressive collapse following the loss of individual load-bearing elements be designed against. Scour effects are to be combatted primarily by the use of piles.

\subsubsection{Determination of tsunami inundation parameters in Japan}

Following GEJE, Japan developed a new tsunami hazard level classification system (Figure 6). As indicated in Table 3, a level 1 tsunami corresponds to fairly frequent tsunami (return period up to 160 years) of a relatively modest inundation depth $(<10 \mathrm{~m})$; level 2 corresponds to rarer events (return period of around a 1000 years) with extensive inundation depth (>10m) (Raby et al., 2015; Shibayama et al., 2013).

For a level 1 event, defences should be built to prevent inundation (Shibayama et al., 2013). Defences should be able to withstand a level 2 tsunami, but it would not be feasible or desirable to build structures that would not be overtopped at this level. As such, non-structural measures must be taken (e.g. evacuation areas, preparedness and planning). This approach involves the preparation of inundation maps corresponding to level 2 tsunamis, provided 
Table 4. Evolution of legislation and guidance documents relevant to tsunami design and planning in Japan (adapted from EEFIT (2013))

\begin{tabular}{|ll}
\hline Year & Summary of regulations \\
\hline 1959 & $\begin{array}{l}\text { Concerning the Prevention of Disasters to Buildings from Storm and Flood Damage (Housing Bureau Notification No. 42) } \\
\text { Sets out the designation of disaster risk zones and states that schools, government offices, public halls and other community } \\
\text { buildings should be sturdy and evacuation areas should be located higher than the predicted inundation depth. }\end{array}$ \\
\hline 1960 & $\begin{array}{l}\text { Building Standard Law of Japan (BSLJ) - Article } 39 \\
\text { The } 1960 \text { update covers tsunami evacuation frameworks and the designation of high-risk areas. Verification of structural safety } \\
\text { against tsunami load is not mandatory (Hitomitsu, 2011). }\end{array}$ \\
\hline 2004 & $\begin{array}{l}\text { Structural Design Method of Buildings for Tsunami Resistance - SDMBTR (Okada et al., 2004) } \\
\text { SDMBTR quantifies tsunami forces on buildings (lateral tsunami force and the effect of buoyancy, as well as load combinations). }\end{array}$ \\
Document in two parts: preliminary discussion and proposed design method (Fukuyama et al., 2012; Shibayama et al., 2013).
\end{tabular}

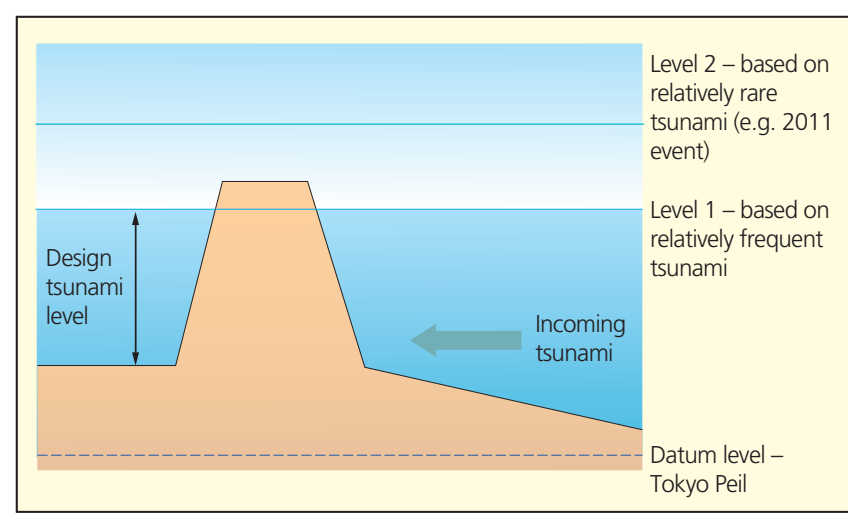

Figure 6. Illustration of level 1 and 2 tsunamis with respect to a coastal defence structure (adapted from Raby et al. (2015))

by municipalities, from which design inundation depths (but no velocities) may be directly obtained.

It must be borne in mind that local geographical areas greatly influence the wave heights for the different levels - that is, there are no level 1 and 2 wave heights that can be uniformly applied across the country (Shibayama et al., 2013).

\subsection{Design guidance in the USA}

\subsubsection{Building design procedure}

The key features of the new ASCE 7-16 (ASCE, 2016) chapter 6 on tsunami loads and effects are described here and in Table 3. For a comprehensive overview of the prescribed design procedure see the paper by Chock (2016).

Structure and component member design is to account for lateral fluid loads, buoyancy and retained water, secondary effects of debris impact and scour. Member design is to account for global lateral loads and local fluid pressures applied directly to the member. Water density is increased to account for small debris and sediment entrained within the inundating flow. Also, opening ratios are limited to capture the effects of debris accumulation (debris damming).

Calculations are made for three stages of the inundating flow process

- maximum overturning condition from combined hydrodynamic and buoyant force

- two-thirds of maximum inundation depth (where velocity is assumed to be at its maximum) for both inflow and outflow

- maximum water depth (assuming velocity equals one-third of maximum in each direction).

Two inflow and drawdown loading cycles (including load reversal) must be considered, as well as the effects of the proceeding design seismic event. Buildings are to be designed to meet specific tsunami performance level objectives depending on the defined risk categories which correspond to building function and occupancy.

\subsubsection{Determination of tsunami inundation parameters}

In the new ASCE 7-16 chapter 6 (ASCE, 2016), offshore tsunami amplitude maps and tsunami design zone maps are provided at a bathymetry contour of $100 \mathrm{~m}$ depth, determined from probabilistic tsunami hazard assessment (Geist and Parsons, 2006; Thio et al., 2012; Wei et al., 2014) for five US states: California, Oregon, Washington, Hawaii, Alaska. The maximum considered tsunami corresponds to a 1-in-2475-year event, chosen for consistency with the return period used for probabilistic seismic hazard assessment under ASCE 7.

Using the run-up points provided in the tsunami design zone maps, determination of inundation parameters at the building site 
is carried out by one of two methods: local-specific numerical inundation modelling for critical buildings, and/or the energy grade line analysis (GLA; Figure 7).

Energy GLA is a calculation method that provides the water depth and velocity using a hydraulic calculation, and it is intended to be statistically conservative in treating the epistemic uncertainty of flow analysis (Chock et al., 2016). It is used to get what would be expected as the velocity for the maximum extent of the inundation. Depth and velocity are related according to the Froude number ( $F r$, a non-dimensional measure of velocity as a function of flow depth), which is assumed to decay with distance inshore as given in Equation 1. Depth is then determined from energy lost over ground.

1. $F r=F r_{0}\left(1-\frac{x}{X_{\mathrm{R}}}\right) \cdot 0 \cdot 5$

where $x$ is the distance inland from the initial shoreline.

In Equation 1 typically $F r_{0}=1$ unless bore conditions exist (characterised by a steep, turbulent broken wave often propagating over standing water). In this case $F r_{0}=1 \cdot 3$, as derived from numerical simulations (Kriebel et al., 2017). See Section 3.2.1 for discussion on the prescriptive flow parameter relationships for peak values.

\subsection{Further design effects not yet considered in current standards}

Best practice for tsunami design of structures is subject to ongoing research. There is a great deal of uncertainty associated with determination of inundation parameters. Regarding fluid-load estimation and structural performance, the areas not considered in current standards are summarised in Table 5.

\section{Comparison of lateral fluid loads}

This section outlines lateral hydrodynamic forces prescribed by US and Japanese design standards, and an alternative force estimate which considers flow regime and blockage ratio. These forces are then quantitatively compared for a case study topography and inundation. Vertical loads (buoyancy and residual water surcharge), debris impact forces and foundation instability effects are not discussed here.

The chosen load cases represent distinct and different loading scenarios covering bores, surges and steady flow conditions. Therefore, the purpose of their comparison is not to assess their accuracy, but to demonstrate the variation in predicted loading on an onshore structure associated with each model, and to present the range of input forces that could be calculated for design purposes.

\subsection{Lateral loads defined in Japanese design guidance}

Under the latest guidance (MLIT, 2011a, 2011b), peak lateral fluid load and the recommended pressure distribution are as shown in Figure 8. Previous design guidance (Japan Cabinet Office, 2005) set the water depth coefficient $(a)$ at 3 based on a study by Okada et al. (2004), who carried out two-dimensional hydraulic model experiments measuring the peak pressures on structures at various distances inland for various wave heights, periods and Froude numbers.

The current guidance defines the water depth coefficient (a) based on studies following GEJE (IIS, 2011) which examined several structures that experienced tsunami flow, including 35 reinforced concrete buildings between one and four storeys. Maximum inundation depth was measured or estimated for the investigated structure, and an equivalent applied hydrostatic force was calculated.

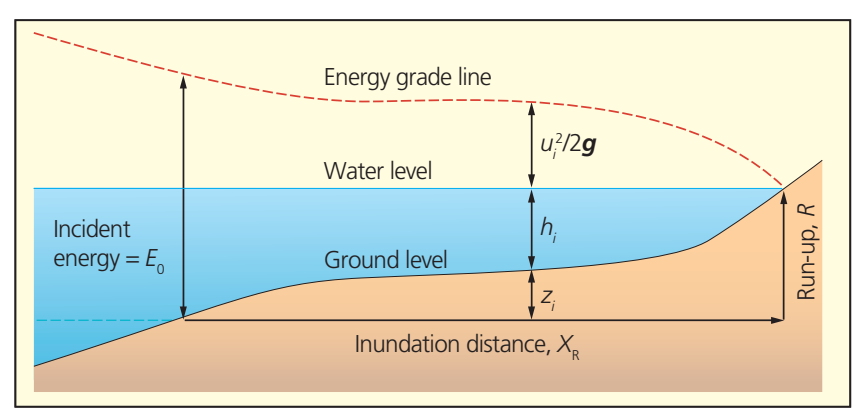

Figure 7. Grade line analysis recommended in ASCE 7-16 (Chock, 2015; Kriebel et al., 2017); $z$ is the elevation, $h$ is the inundation depth, $u$ is the flow velocity; the subscript $i$ denotes the $i$ th segment of the discretised ground elevation

Table 5. Considerations not yet sufficiently covered in current standards

\begin{tabular}{|c|c|c|}
\hline & Consideration & Description \\
\hline \multirow[t]{3}{*}{$\begin{array}{l}\text { Load } \\
\text { estimation }\end{array}$} & $\begin{array}{l}\text { Load estimation considering } \\
\text { flow regime and blockage } \\
\text { ratio }\end{array}$ & $\begin{array}{l}\text { Alternative load estimations consider how fluid loads are affected by flow depth changes } \\
\text { between the front and rear of the building (Cunningham et al., 2014; Foster et al., 2017; } \\
\text { Pringgana et al., 2016). }\end{array}$ \\
\hline & $\begin{array}{l}\text { Vertical distribution of lateral } \\
\text { fluid pressure }\end{array}$ & $\begin{array}{l}\text { Varying distributions exist in the literature (e.g. triangular or uniform distributions) which affect } \\
\text { global and member design (Macabuag et al., 2014). }\end{array}$ \\
\hline & Time-dependent loads & \multirow{3}{*}{$\begin{array}{l}\text { The quasi-static tsunami loadings prescribed do not fully account for the transient nature of } \\
\text { the actual load and impacted structure's time-dependent response. Structural ductility, over- } \\
\text { strength and dynamic properties play a central role in seismic design, and it is not clear if such } \\
\text { considerations may have implications for tsunami design (Petrone et al., 2017). }\end{array}$} \\
\hline \multirow{3}{*}{$\begin{array}{l}\text { Structural } \\
\text { response }\end{array}$} & Dynamic structural response & \\
\hline & Ductility and over-strength & \\
\hline & $\begin{array}{l}\text { Combination of seismic and } \\
\text { tsunami loads }\end{array}$ & $\begin{array}{l}\text { The combination of seismic and tsunami damage for near-field tsunami (Figure 3) may limit the } \\
\text { capacity of the structure under tsunami loading, due to the cyclical degradation of structural materials } \\
\text { loaded into the ductile range or damage to in-fill panels and stiffening elements, reducing capacity. } \\
\text { Such effects are discussed in ASCE 7-16, but are yet to be quantified (e.g. Scott and Mason, 2017). }\end{array}$ \\
\hline
\end{tabular}


Tsunami design procedures for engineered buildings: a critical review

Macabuag, Raby, Pomonis et al.

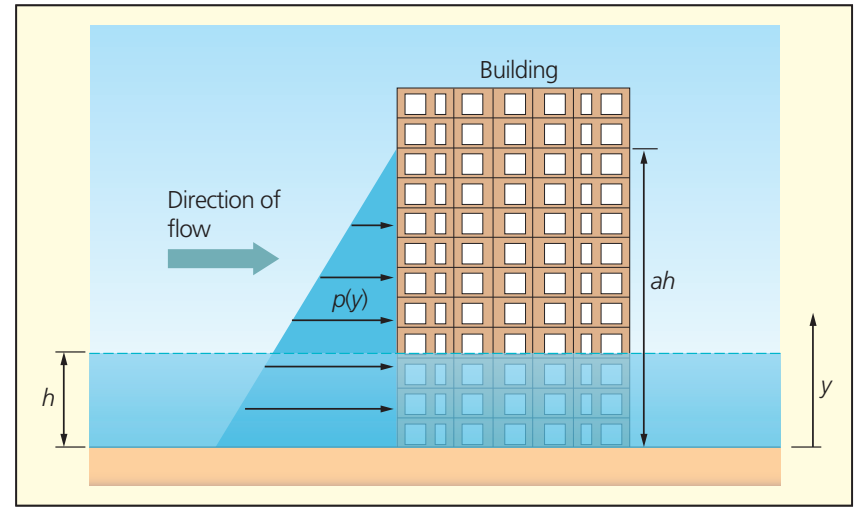

Figure 8. Equivalent static loading recommended as design loading in MLIT 2570. $p(y)$ is defined in Equation 2

By comparing the applied force with the estimated capacity of the structure, for collapsed and non-collapsed structures, the water depth coefficient $(a)$ in Figure 8 could be estimated. As such, for collapse-prevention design purposes, it was considered that the use of an equivalent hydrostatic force, as per Japan Cabinet Office (2005), to estimate tsunami loading was adequate (Equation 2), where $a$ is defined as in Table 6 .

2. $p(y)=\rho g(a h-y)$

where $p(y)$ is the pressure at height $y$ above the ground level; $\rho$ is the water density; $g$ is acceleration due to gravity; and $h$ is the inundation depth at the building location, as defined in Figure 8.

This hydrostatic approximation was also compared to a hydrodynamic approximation by assuming both the drag and hydrostatic approximations of the loading to be equivalent, so that $\mathrm{Fr}$ and $a$ can be equated as shown in Equations 3 and 4 (IIS, 2011). The proposed relationship is evidenced, up to the maximum value of $a=3$, by the experimental data of Asakura et al. (2000).

3. $F_{\text {hydrostatic }}=F_{\text {drag }} \rightarrow \frac{a^{2}}{2}\left(h^{2} \rho \mathbf{g}\right)=F r^{2}\left(h^{2} \rho \mathbf{g}\right)$

\section{4. $\therefore a=F r \sqrt{2}$}

Therefore, the peak load estimation presented in Equation 2 is not proposed as an accurate depiction of the flow regime (i.e. it is not expected that tsunami flow will apply a purely hydrostatic load on only one side of a building with no inundation pressure on the other side). Rather, it is an equivalent estimate of peak lateral load depending only on the peak inundation depth, which approximates the flow Froude number based on distance from the shore and the presence or not of seaward obstacles (with the specified values of $a=1 \cdot 5,2$ and 3, corresponding to $F r=1 \cdot 06$, $1 \cdot 41$ and $2 \cdot 12$, respectively). This is advantageous to a designer as peak inundation depth is more readily calculated than other flow parameters, such as velocity and momentum flux.

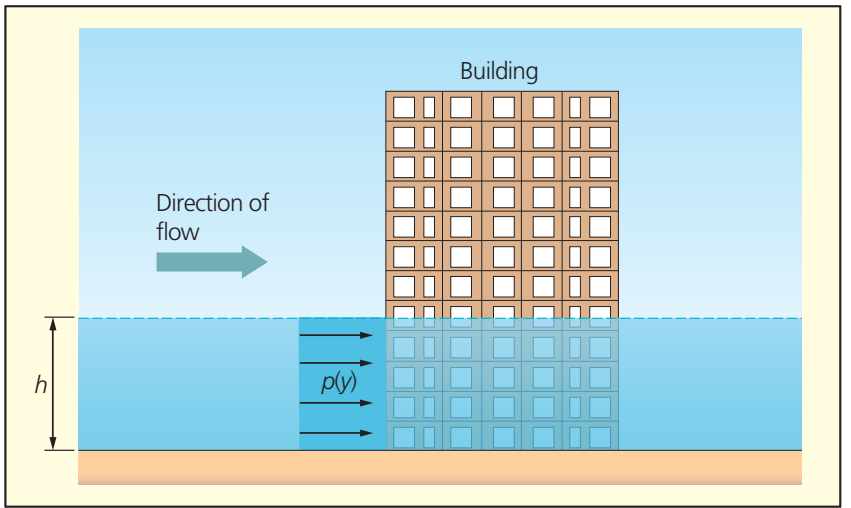

Figure 9. Uniformly distributed hydrodynamic loading recommended in FEMA P646 (FEMA, 2012)

Table 6. Water depth coefficient (a) as a function of distance from water source and presence of sheltering structures (Fukuyama et al., 2012; MLIT, 2011b)

\begin{tabular}{lll} 
& $\begin{array}{l}\text { With shelter } \\
\text { between the } \\
\text { facility and the } \\
\text { incoming wave }\end{array}$ & $\begin{array}{l}\text { No shelter } \\
\text { between the } \\
\text { facility and the } \\
\text { incoming wave }\end{array}$ \\
\hline $\begin{array}{l}\text { Distance from } \\
\text { shoreline or rivers }\end{array}$ & $>500 \mathrm{~m}<500 \mathrm{~m}$ & Any distance \\
\hline $\begin{array}{l}\text { Water depth } \\
\text { coefficient, a } \\
\text { (Figure 8) }\end{array}$ & 1.5 & 3 \\
\hline
\end{tabular}

\subsection{Lateral hydrodynamic drag defined in US guidance}

Hydrodynamic forces are shown in Figure 9 and Equations 5 and 6

\section{5. $\quad F_{\text {drag }}=0 \cdot 5 k_{\mathrm{s}} \rho_{\text {sw }} C_{\mathrm{d}} B\left(h u^{2}\right)$}

6. $F_{\text {impulse }}=1 \cdot 5 F_{\text {drag }}$

where $k_{\mathrm{s}}$ is a factor accounting for accumulated debris in the flow; $\rho_{\text {sw }}$ is the sea water density; $C_{\mathrm{d}}$ is the drag coefficient; $B$ is the building width; and $h u^{2}$ is the momentum flux. Various studies find that the initial impulsive (bore impact) force $\left(F_{\text {impulse }}\right)$ can be greater than the drag force $\left(F_{\mathrm{drag}}\right)$ on a structure (Lloyd and Rossetto, 2012; Robertson et al., 2011) when there is standing water. The bore impact force is therefore defined as a multiple of the drag force Equation 6, an approach which originates from $\mathrm{CCH}-2000(\mathrm{CCH}$, 2000; Table 7).

It is noted that the peak drag force does not occur at the maximum inundation depth, but at the point at which the momentum flux $\left(h u^{2}\right)$ peaks. Therefore, for a given maximum inundation depth at a building, the peak force occurs at a lower inundation depth than that maximum one.

For a comprehensive summary of the load estimation procedures of ASCE 7 (ASCE, 2016) the reader is referred to the paper by Chock (2016). 
Table 7. Legislation and guidance documents relevant to tsunami design in the USA

\begin{tabular}{|c|c|}
\hline Year & Summary of regulations \\
\hline 2000 & $\begin{array}{l}\text { The City and County of Honolulu Building Code }(\mathrm{CCH}, 2000) \\
\text { Guidance for flood-proofing and structural requirements, including tsunami effects. Bore velocity taken as equal to bore depth, while } \\
\text { scour is predicted based on distance from shoreline and soil type. Formulae provided for forces due to coastal flooding including } \\
\text { buoyant, surge, drag, hydrostatic and debris-impact forces (Shibayama et al., 2013). }\end{array}$ \\
\hline 2005 & $\begin{array}{l}\text { American Society of Civil Engineers Code (ASCE/SEI 24-05) } \\
\text { Minimum requirements for flood-resistant design and construction, complying with FEMA and National Flood Insurance Program } \\
\text { (NFIP) requirements. Referenced by the International Building Code 2006. ASCE/SEI } 24-05 \text { refers to ASCE 7-05 for flood loads: } \\
\text { including hydrostatic, hydrodynamic, wave and debris loads, as well as load combinations. }\end{array}$ \\
\hline 2005 & $\begin{array}{l}\text { Federal Emergency Management Agency (FEMA) Coastal Construction Manual, 3rd edition (FEMA 55) (FEMA, 2005) } \\
\text { Chapter } 11 \text { includes site-specific tsunami loads and load combinations. Flood loads consider flood depth, wave set-up, wave height, } \\
\text { flood velocity, hydrostatic loads, breaking wave loads on piles and walls, and debris impact, assuming that tsunami loads can be } \\
\text { calculated similarly to other flood loads (Shibayama et al., 2013). }\end{array}$ \\
\hline 2008 & $\begin{array}{l}\text { FEMA Guidelines for Design of Structures for Vertical Evacuation from Tsunamis (FEMA P646) (FEMA, 2008) } \\
\text { Provides guidance for calculating tsunami loads on structures, and provides equations for hydrostatic, hydrodynamic and debris forces. }\end{array}$ \\
\hline 2009 & $\begin{array}{l}\text { FEMA Guidelines for Vertical Evacuation from Tsunamis for Community Officials (FEMA P646A) (FEMA, 2009) } \\
\text { A largely non-technical document, aimed at state and local government officials to explain how to fund, design and build the vertical } \\
\text { evacuation structure. }\end{array}$ \\
\hline 2010 & $\begin{array}{l}\text { American Society of Civil Engineers Standard ASCE/SEI 7-10 } \\
\text { Describes flood and wave forces (tides, storm surges, riverine flooding). Chapter } 5 \text { provides formulas to calculate wave loads and } \\
\text { breaking wave loads on piles and walls. Hydrodynamic loads are converted into equivalent hydrostatic forces when flow velocity is below } \\
3.05 \mathrm{~m} / \mathrm{s} \text {, otherwise fluid dynamics must be used. Note that this document does not specifically contain formulas for tsunami loading. }\end{array}$ \\
\hline 2011 & Great East Japan Earthquake and Tsunami (GEJE) \\
\hline 2012 & $\begin{array}{l}\text { FEMA Guidelines for Design of Structures for Vertical Evacuation from Tsunamis, 2nd edition (FEMA P646) (FEMA, 2012) } \\
\text { Version updates include observations from GEJE and revision of formulae for debris impact loading. }\end{array}$ \\
\hline 2017 & $\begin{array}{l}\text { ASCE 7-16 (ASCE, 2016) chapter } 6 \text { : tsunami loads and effects } \\
\text { Contains a new chapter } 6 \text { which quantifies various tsunami loads and effects, and prescribes a design procedure incorporating aspects } \\
\text { of performance-based tsunami engineering. The document includes also a commentary section and is written in mandatory language. }\end{array}$ \\
\hline
\end{tabular}

\subsection{Alternative lateral load definitions}

Foster et al. (2017) and Qi et al. (2014) define an alternative steady-state force estimation considering choked and sub-critical flow for a body of width $b$ in a channel of width $w$ (Figure 10). It is evaluated by way of two different flow regimes determined by Froude number. The equations relate $h, u$ (the flow velocity upstream of a building, as shown in Figure 10) and the blockage ratio (building width/channel width, where channel width is the distance, orthogonal to flow, between adjacent obstacles either side of the building) to the force, denoted here as $F_{\mathrm{OS}}$.

Increasing the blockage ratio generally has the effect of increasing the force on the structure (Foster et al., 2017) for the calculation procedure. Defining an accurate blockage ratio would require knowledge of the flow direction in order to define the cross-section for which 'building width' and 'channel width' could be measured.

In Equation $7, \lambda$ is a function of hydrostatic and form drag coefficients, and up- and down-stream Froude numbers, and $F r_{\mathrm{c}}$ is the critical Froude number, and is a function of drag coefficient and blockage ratio $(b / w)$.

7. $F_{\mathrm{QS}}=\left\{\begin{array}{rr}\frac{1}{2}\left\{C_{\mathrm{D} 0}\left[1+\frac{C_{\mathrm{D} 0}}{2}\left(\frac{b}{w}\right)\right]\right\} \rho v^{2} h, & F r<F r_{\mathrm{c}} \\ \lambda \rho \boldsymbol{g}^{1 / 3} v^{4 / 3} h^{4 / 3}, & F r \geq F r_{\mathrm{c}}\end{array}\right.$

where $C_{\mathrm{D} 0}$ is the hydrodynamic drag coefficient where the blockage ratio is 0 .

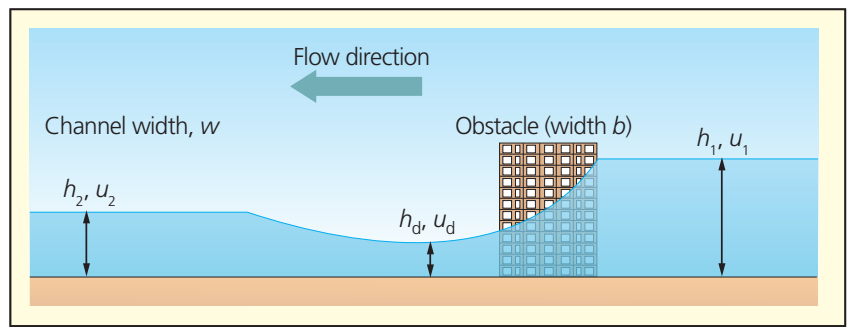

Figure 10. Choked flow, characterised by a large change in inundation depths between the upstream (denoted with subscript 1) and downstream (denoted with subscripts $d$ and 2) sides of a building (adapted from Foster et al. (2017))

\subsection{Quantitative comparison for a case study topography and inundation scenario}

The various definitions of lateral fluid load presented above are quantitatively compared below, for square plan buildings orientated such that their flat surface is orthogonal to the oncoming flow.

A rigorous comparative study of loads would require multiple beach profiles and Manning coefficients, as well as a range of offshore tsunami conditions and run-ups. The purpose of this study, however, is to use a single case study to highlight the variability in resultant load due to differing load formulations.

The case study chosen (Figure 11) is a uniform 1:20 beach (as in FEMA P646 (FEMA, 2012)), characterised by a Manning 
Civil Engineering

Volume 171 Issue CE4
Tsunami design procedures for engineered

buildings: a critical review

Macabuag, Raby, Pomonis et al.

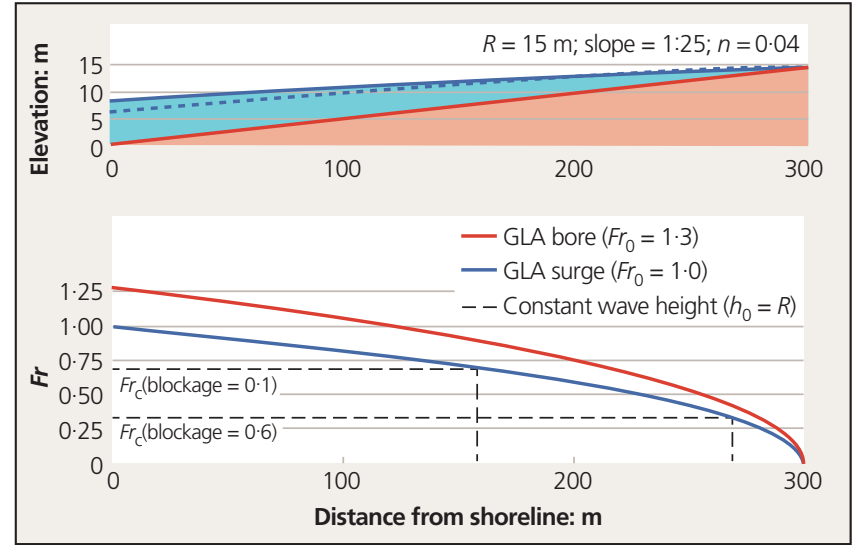

Figure 11. Case study topography and flow conditions derived from grade line analysis for bore ( $F r_{0}=1 \cdot 3, L C 5$, dashed line) and surge $\left(F r_{0}=1\right.$, load-cases: LC4, LC6, LC7, solid line) conditions. The critical Froude numbers $(F r)$ defining choked and sub-critical flow in load cases LC6 and LC7 are shown, as well as the distance inland at which critical conditions cease. The shaded water-level indicates surge conditions defined by grade line analysis. Load case numbers and references correspond to those given in Table 8

coefficient of $n=0.04$ (representing buildings of urban density (table 6.6_1 in ASCE 7-16 (ASCE, 2016)), experiencing a tsunami with a run-up of $R=15 \mathrm{~m}$. For consistency, energy GLA is used to determine the variation of depth and velocity up the beach.

\subsubsection{Comparison of lateral fluid loads}

Lateral fluid loads applied to on-shore, bluff structures under idealised perpendicular wave approach are compared. Table 8 presents the examined load cases. For comparison, the lateral fluid

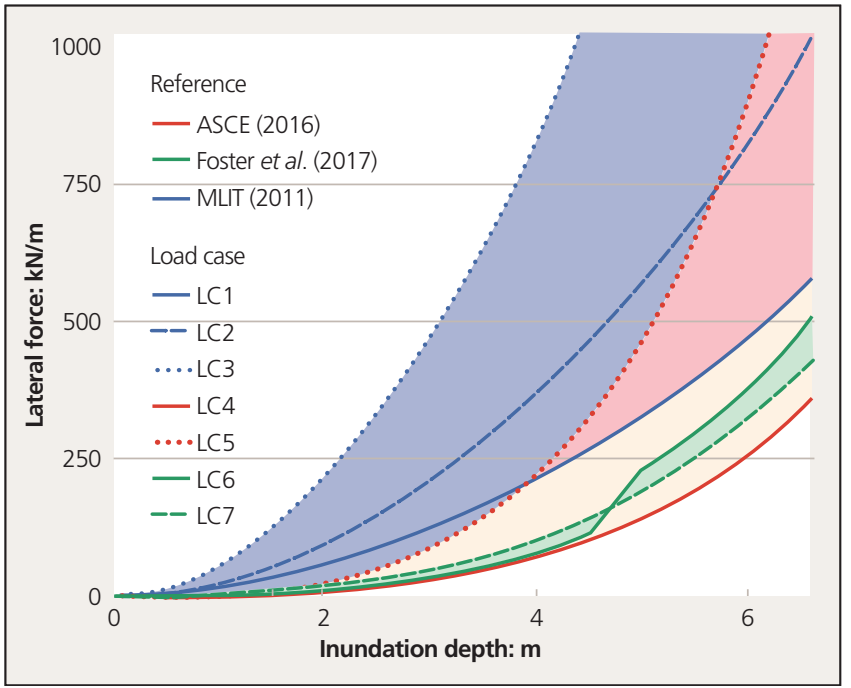

Figure 12. Comparison of loads for the case study topography and inundation. Load case numbers and references correspond to those given in Table 8 and shaded areas correspond to the upper and lower bounds for each load reference

force for each load case is plotted against inundation depth. The comparison of the loads calculated for each load case is shown in Figure 12.

MLIT load cases (LC1-LC3) give consistently higher load estimates when compared with the drag load cases (LC4, LC6, LC7), which agrees with load comparison studies by Yeh et al. (2005).

Considering load estimates according to Foster et al. (2017) (LC6, LC7) the load applied to sparsely spaced buildings (LC6) shows a clear increase at the change between sub-critical and

Table 8. Load cases used to calculate hydrodynamic loads - values for drag force coefficients $\left(C_{D^{\prime}} C_{D 0}\right)$ are derived from their respective references

\begin{tabular}{|c|c|c|c|c|}
\hline $\begin{array}{l}\text { Tsunami } \\
\text { load case }\end{array}$ & Reference & Description of loading & $\begin{array}{l}\text { Determination of flow } \\
\text { conditions as a function } \\
\text { of inundation depth, } h\end{array}$ & $\begin{array}{l}\text { Determination of } \\
\text { force (Equation) }\end{array}$ \\
\hline LC1 & \multirow[t]{3}{*}{$\begin{array}{l}\text { MLIT } 2570 \\
\text { (MLIT, 2011b) }\end{array}$} & $\begin{array}{l}\text { Equivalent hydrostatic pressure, }<500 \mathrm{~m} \text { from the water source } \\
\text { with shelter from the incoming wave }\end{array}$ & \multirow{3}{*}{$\begin{array}{l}\text { NA } \\
\text { (no further parameters } \\
\text { required) }\end{array}$} & $\begin{array}{c}(2) \\
a=1 \cdot 5\end{array}$ \\
\hline LC2 & & $\begin{array}{l}\text { Equivalent hydrostatic pressure, }>500 \mathrm{~m} \text { from the water source } \\
\text { with shelter from the incoming wave }\end{array}$ & & $\begin{array}{c}(2) \\
a=2\end{array}$ \\
\hline LC3 & & $\begin{array}{l}\text { Equivalent hydrostatic pressure, no shelter from the incoming } \\
\text { wave }\end{array}$ & & $\begin{array}{c}(2) \\
a=3\end{array}$ \\
\hline LC4 & $\begin{array}{l}\text { ASCE 7-16 } \\
\text { (ASCE, 2016) }\end{array}$ & Hydrodynamic drag & \multirow{4}{*}{$\begin{array}{l}\text { Grade line analysis } \\
\text { (Figure } 7 \text { ) } \\
R=15 \mathrm{~m} \\
\text { uniform } 1: 20 \text { beach } \\
n=0.04\end{array}$} & $\begin{array}{c}(5) \\
C_{D}=2\end{array}$ \\
\hline LC5 & & Bore impact & & (6) \\
\hline LC6 & \multirow[t]{2}{*}{$\begin{array}{l}\text { Foster et al. } \\
\text { (2017) }\end{array}$} & $\begin{array}{l}\text { Hydrodynamic drag accounting for flow regime (Fr), sparse } \\
\text { buildings }\end{array}$ & & $\begin{array}{c}(7) \\
C_{D 0}=1.9 \\
b / w=0.1\end{array}$ \\
\hline LC7 & & $\begin{array}{l}\text { Hydrodynamic drag accounting for flow regime (Fr), dense } \\
\text { buildings }\end{array}$ & & $\begin{array}{c}(7) \\
C_{D 0}=1.9 \\
b / w=0.6\end{array}$ \\
\hline
\end{tabular}


choked flow. However, for more densely spaced buildings (LC7), flow is choked for almost all inundation depths, and so the load jump is not visible in Figure 12. Sub-critical loads defined by Foster et al. (2017) are very similar to the ASCE drag force (LC4). However, for choked conditions, Foster et al. (2017) loads are higher than the ASCE drag force (LC4).

The above suggests that use of the standard drag force equation (LC4) without considering flow regime may be unconservative in some cases, particularly in dense urban environments. This is somewhat addressed in ASCE 7-16 (ASCE, 2016) by consideration of flow velocity amplification due to upstream obstructing structures. However, the current provisions do not explicitly consider the effect of choked flow conditions on the obstructing structure itself (see Section 4.3), only the increased velocity and altered flow direction downstream of the structure.

\subsubsection{Comparison of loading assumptions}

The load variability shown in Figure 12 is explained when considering the range of assumptions that have been made. Table 9 summarises the inundation parameters used for force estimation, and Figure 13 shows the range of blockage ratio and $\mathrm{Fr}$ assumptions for each load case.

The MLIT load cases represent scenarios of fixed $\mathrm{Fr}$ (see Section 4.1). The specified water depth coefficients $(a)$ are correlated with building damage data from the 2011 tsunami, where in reality flow experienced a range of blockage ratios, and so a range is shown in Figure 13 (blockage ratio of $0 \cdot 1$ to $0 \cdot 9$ ). This leads to LC1-LC3 being represented by straight lines, such that the $F r$ and blockage ratio combination represented by each load case can lie anywhere along its respective line.

As the ASCE drag equation (LC4) may be unconservative for choked conditions, then LC4 is depicted in Figure 13 as the shaded area defined by a Froude number less than the critical Froude number for which conditions become choked $\left(F r<F r_{c}\right.$, where $F r_{c}$ is a function of blockage ratio). The load factor applied to calculate the ASCE bore impact loads (LC5, Figure 9) is derived from a series of flume experiments of various blockage ratios (Nistor et al., 2009), with Kriebel et al. (2017) defining $F r=1 \cdot 3$ at the shore. Figure 13 therefore shows LC5 as the area defined

Table 9. Comparison of input variables required for force estimation formulae of the references considered

\begin{tabular}{lll} 
Reference & $\begin{array}{l}\text { Required input } \\
\text { variables } \\
\text { for force } \\
\text { estimation }\end{array}$ & Notes \\
\hline $\begin{array}{l}\text { MLIT 2570 } \\
\text { (MLIT, } \\
\text { 2011b) }\end{array}$ & $h, a$ & $\begin{array}{l}\text { a is a function of distance inland } \\
\text { and seaward barriers, and can } \\
\text { be considered a proxy for } F r \text { (see } \\
\text { Section 4.1). }\end{array}$ \\
$\begin{array}{l}\text { ASCE 7-16 } \\
\text { (ASCE, 2016) }\end{array}$ & $h, v$ & \\
\hline $\begin{array}{l}\text { Foster et al. } \\
\text { (2017) }\end{array}$ & $h, v, b / w$ & $\begin{array}{l}\text { b/w = building width / channel } \\
\text { width, }\end{array}$ \\
& & $\begin{array}{l}\text { where channel width is the } \\
\text { distance, orthogonal to flow, } \\
\text { between adjacent obstacles } \\
\text { either side of the building. }\end{array}$
\end{tabular}

by $F_{r}<1 \cdot 3$ for any blockage ratio. The Foster et al. (2017) load estimation methodology can consider any $F r$ and blockage ratio, but in the case study scenario LC6 and LC7 take the specific values shown in Figure 13.

Figure 13 shows that the MLIT load cases consider the highest $F r$ scenarios. The LC4 area is defined by the condition $F r<F r_{\text {c }}$, which highlights that LC4 may be unconservative for scenarios for which flow is expected to be choked. This is shown by the load cases of Foster et al., (2017), where LC6 (sparse buildings) is subcritical for $F r$ values corresponding to lower inundation, but for LC7 (dense buildings) flow is mostly choked.

In addition to differences in flow regime (defined by $\mathrm{Fr}$ ) and blockage ratio assumptions, the MLIT and ASCE standards also consider different structural reliability and performance objectives. This effect should be somewhat limited in the comparison between the ASCE and Foster et al. (2017) load estimations, as the same energy GLA has been conducted to derive the flow conditions for both sets of load cases. Nonetheless, the reader is referred to the paper by Chock et al. (2016) for further discussion on treatment of structural reliability and performance within ASCE 7-16.

\section{Discussion and conclusions}

This paper outlines key engineering principles of tsunami design of buildings, compares how these principles are addressed by the US (ASCE 7-16) and Japanese (MLIT 2570) standards (Table 3), outlines considerations not yet covered (Table 5), and quantitatively compares code-prescribed lateral hydrostatic forces with an alternative force estimation method considering the flow regime (indicated by Froude number) and building density (Figure 12).

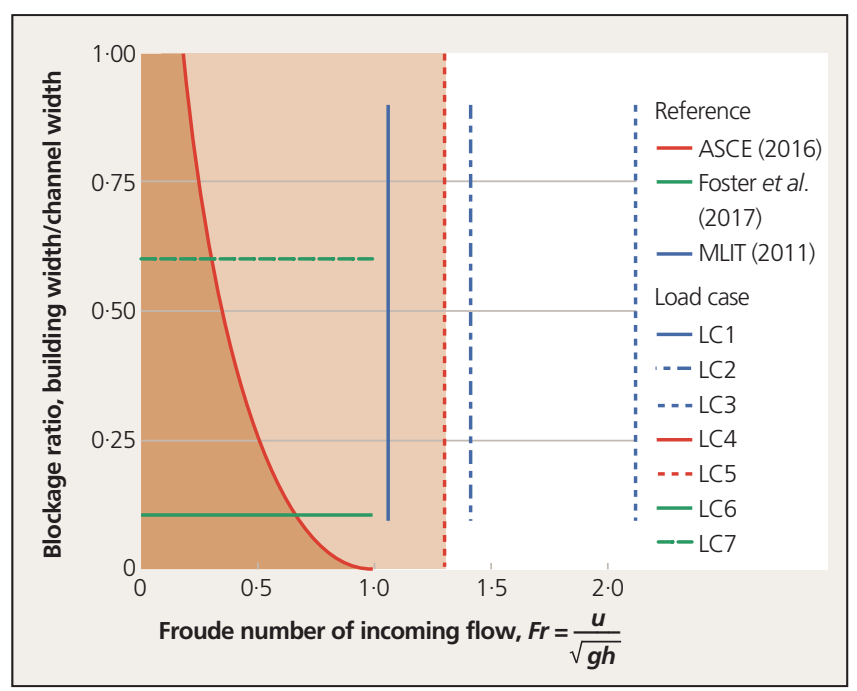

Figure 13. Comparison of blockage ratio and Froude number assumptions for the conditions of the chosen case study. Load case numbers and references correspond to those given in Table 8 . The blockage ratio and Froude number assumptions are limited to points on the lines shown for each load case, with the exceptions of load cases LC4 and LC5 which may occupy any point within their respective shaded areas 
The pseudo-static approach of the Japanese guidelines (shown to approximate to the standard hydrodynamic drag equation with varying Froude numbers) avoids the need for inundation velocity estimates which are difficult to obtain accurately, even when using a detailed numerical inundation model, due to the significant uncertainties in the estimation of the tsunamigenic source parameters. This approach is derived from the results of laboratory experiments adjusted to incorporate a statistical treatment of damage data from GEJE. Therefore, it inherently includes consideration of debris damage and other effects.

However, it is not clear if it is applicable to topographical and flow conditions different from those experienced during GEJE. Conversely, US design formulae are analytically derived, but require accurate inundation modelling to derive inundation velocities. This requirement is overcome in the USA by the provision of run-up and offshore wave information suitable for numerical inundation modelling or grade line analysis, but outside the US will require a means of estimating flow velocities in the absence of such data.

A high degree of variability in the resulting load estimates is found (Figure 12), demonstrating uncertainty in not only determining the tsunami inundation parameters, but also their effect on buildings. For the chosen single-case study topography and inundation, it is shown that load estimates in Japanese guidance are highly conservative, and that the standard drag equation (used by ASCE 7-16) may be unconservative for higher Froude numbers and blockage ratio conditions, where consideration of the flow regime would be preferred. The variability in load estimate is explored further by graphically representing the underlying assumptions behind each considered load case (Figure 13), demonstrating that the flow scenarios differ for each case.

Note also that for brevity debris and foundation effects have been ignored in this review. However, these are important issues requiring further investigation. For example, ASCE 7 describes scour as a function of inundation depth alone without considering soil characteristics, and Japanese guidelines merely prescribe the use of deep foundations without guidance on appropriate depth and other design measures.

Therefore, it is critical that designers, assessors and researchers apply engineering judgement to identify the relevant loading scenarios properly. Care is especially required for accurate modelling of damage for catastrophe modelling or performance-based design purposes. In such cases, necessarily conservative code prescriptions may lead to inaccurate damage assessment conclusions.

This study does not attempt to replicate information already provided in design guidance documents, but to

- outline what further research is needed

- inform those responsible for the development of new design standards in at-risk locations

- enable practising engineers to make informed decisions by identifying for which design cases current guidance is applicable

- highlight conditions not yet covered in design standards.

The tsunami design prescriptions and guidelines available in Japan and the USA have been developed by experienced researchers and engineers. Discrepancies are judged to have occurred due to different developmental paths, a lack of measurement data of actual tsunami actions on structures, difficulties in recreating these effects experimentally or numerically and, most importantly, due to the different approach in protection practices and philosophy in the case of such disasters.

The precedence of large tsunamis indicates that the risk for some of Europe's coastlines is significant. Therefore, engineering codes of practice should be developed for the design of critical infrastructure, evacuation buildings and sea defences, in at-risk locations around tsunami-prone areas.

\section{Acknowledgements}

This paper is based on collected data and analyses results obtained from two field studies conducted following GEJE by EEFIT in 2011 and 2013. Special acknowledgement must be made to the kind contributions of colleagues and individuals involved in tsunami design standards development in Japan, USA and Canada, as well as to colleagues at IRIDeS Tohoku University Japan for assisting multiple visits to Japan. The first author was funded by the UK Research Council Engineering and Physical Sciences Research Council (EPSRC) engineering doctorate programme and the Willis research network. The EEFIT work presented in this paper was funded by the EPSRC, grant (EP/I01778X/1, EP/P025641/1) and the authors gratefully acknowledge this assistance.

\section{References}

Arikawa T, Shimosako K and Ishikawa N (2012) Structural failure by impulsive tsunami force. In 5th International Conference on Protection of Structures Against Hazards (Lok TS and Hao H (eds)). CI-Premier Conference Organisation, Singapore (CD-ROM).

Asakura R, Iwase K, Ikeya T et al. (2000) Experimental study on wave force acting on on-shore structures due to overflowing tsunamis. Proceedings of Coastal Engineering, JSCE 47: 911-915 (in Japanese)

ASCE (American Society of Civil Engineers) (2016) ASCE 7-16: Minimum design loads and associated criteria for buildings and other structures. ASCE, Reston, VA, USA.

CCH (City and Council of Honolulu) (2000) Revised Ordnances of Honolulu. Chapter 16, Building Code. Article 11: Regulations Within Flood Hazard Districts and Developments Adjacent to Drainage Facilities. Department of Planning and Permitting of Honolulu, Honolulu, HI, USA. See https:// www.honolulu.gov/rep/site/ocs/roh/ROHChapter16a11.pdf (accessed 24/04/2018)

Chock G (2015) The ASCE 7 tsunami loads and effects design standard for the United States. In Handbook of Coastal Disaster Mitigation for Engineers and Planners (Esteban M, Takagi H and Shibayama T (eds)) Elsevier, Amsterdam, the Netherlands, ch. 21, pp. 437-460.

Chock GYK (2016) Design for tsunami loads and effects in the ASCE 7-16 standard. Journal of Structural Engineering, ASCE 142(11): 04016093, https://doi.org/10.1061/(ASCE)ST.1943-541X.0001565.

Chock GYK, Robertson IN, Kriebel D, Francis M and Nistor I (2013) Tohoku, Japan, Earthquake and Tsunami of 2011: Performance of Structures under Tsunami Loads. American Society of Civil Engineers, Reston, VA, USA

Chock G, Yu G, Thio HK and Lynett PJ (2016) Target structural reliability analysis for tsunami hydrodynamic loads of the ASCE 7 standard. Journal of Structural Engineering, ASCE 142(11): 04016092, https://doi. org/10.1061/(ASCE)ST.1943-541X.0001499.

Cunningham LS, Rogers BD and Pringgana G (2014) Tsunami wave and structure interaction: an investigation with smoothed-particle hydrodynamics. Proceedings of the Institution of Civil Engineers Engineering and Computational Mechanics 167(3): 126-138, https://doi. org/doi:10.1680/eacm.13.00028. 
EEFIT (Earthquake Engineering Field Investigation Team) (2011) The $M 9.0$ Töhoku Earthquake and Tsunami of 11th March 2011: A Field Report by EEFIT. EEFIT, Institution of Structural Engineers, London, UK.

EEFIT (2013) Recovery Two Years after the 2011 Tohoku Earthquake and Tsunami: A Return Mission Report By EEFIT. EEFIT, Institution of Structura Engineers, London, UK.

FEMA (Federal Emergency Management Agency) (2005) Coastal Construction Manual, 3rd edition. FEMA, Washington, DC, USA, FEMA 55.

FEMA (2008) Guidelines for Design of Structures for Vertical Evacuation from Tsunamis. FEMA, Washington, DC, USA, FEMA P646.

FEMA (2009) Vertical Evacuation from Tsunamis: A Guide for Community Officials. FEMA, Washington, DC, USA, FEMA P646A.

FEMA (2012) Guidelines for Design of Structures for Vertical Evacuation from Tsunamis, 2nd edn. FEMA, Washington, DC, USA, FEMA P646.

Foster ASJ, Rossetto T and Allsop W (2017) An experimentally validated approach for evaluating tsunami inundation forces on rectangular buildings. Coastal Engineering 128: 44-57.

Fraser S, Raby A, Pomonis A et al. (2012) Tsunami damage to coastal defences and buildings in the March 11th 2011 M w 9.0 Great East Japan earthquake and tsunami. Bulletin of Earthquake Engineering 11(1) 205-239, https://doi.org/10.1007/s10518-012-9348-9.

Fukuyama $\mathrm{H}$, Kato $\mathrm{H}$, Ishihara $\mathrm{T}$ et al. (2012) Structural design requirement on the tsunami evacuation buildings. 14th U.S.-Japan Workshop on the Improvement of Structural Design and Construction Practices, Makena Alanui, HI, USA. See http://www.nehrp.gov/pdf/UJNR_2013_Tsunami_ Manuscript.pdf (accessed 24/04/2018)

Geist EL and Parsons T (2006) Probabilistic analysis of tsunami hazards. Natural Hazards 37(3): 277-314, https://doi.org/10.1007/s11069-0054646-z.

Hitomitsu K (2011) Tsunami-induced damage to buildings and related activities by NILIM, BRI and MLIT. IRCC Workshop, Gold Coast, Australia. See http://www.irccbuildingregulations.org/pdf/07kikitsu_japan.pdf (accessed 24/07/2017).

IIS (Institute of Industrial Science) (2011) Interim Report of the Building Standards Improvement Promotion Project no. 40 - A Study of Improvement of Building Standards etc in Tsunami Critical Areas. Institute of Industrial Science, University of Tokyo, Tokyo, Japan (in Japanese). See http://www.mlit.go.jp/common/000172791.pdf and http://www.mlit. go.jp/common/000172792.pdf (accessed 16/05/2018).

Japan Cabinet Office (2005) Tsunami Evacuation Building Guidelines (津波 避難ビル等に係るガイドライン). Japan Cabinet Office, Tokyo, Japan (in Japanese). See http://www.bousai.go.jp/kohou/oshirase/h17/pdf/ guideline.pdf (accessed 05/12/2015)

Kriebel DL, Lynett PJ, Cox DT et al. (2017) Energy method for approximating overland tsunami flows. Journal of Waterway, Port, Coastal and Ocean Engineering 143(5): 04017014, https://doi.org/10.1061/(ASCE)WW.19435460.0000393

Lloyd TO and Rossetto T (2012) A comparison between existing tsunami load guidance and large-scale experiments with long-waves. 15th World Conference on Earthquake Engineering, Lisbon, Portugal.

Macabuag J, Rossetto T and Lloyd T (2014) Sensitivity analysis of a framed structure under several tsunami design-guidance loading regimes. 2nd European Conference on Earthquake Engineering and Seismology, Istanbul, Turkey.

McCabe MV, Stansby PK, Cunningham LS and Rogers BD (2014) Modelling the impact of tsunamis on coastal defences in the UK. In 34th International Conference on Coastal Engineering (ICCE 2014) (Lynett $P$ (ed.)). Curran Associates, Red Hook, NY, USA, vol. 3, pp. 2470-2481.

MLIT (Ministry of Land, Infrastructure, Transport and Tourism) (2011a) Concerning Setting the Safe Structure Method for Tsunamis which are Presumed when Tsunami Inundation Occurs - Note 1318. MLIT, Tokyo, Japan.

MLIT (2011b) Further Information Concerning the Design Method of Safe Buildings that are Structurally Resistant to Tsunamis - Technical Advice No. 2570. MLIT, Tokyo, Japan.
Nassirpour A (2012) Analysis of Tsunami Events and Run-up. MEng thesis, University College London, London, UK.

NGDC NOAA (National Geophysical Data Center National Oceanic and Atmospheric Administration) (2013) NGDC/WDS Global Historical Tsunami Database, 2100 BC to Present. NOAA, Silver Spring, MD, USA. See https://doi.org/doi:10.7289/N5PN93H7 (accessed 24/04/2018).

Nistor I, Palermo D, Nouri Y and Murty T (2009) Tsunami-induced forces on structures. In Handbook of Coastal and Ocean Engineering (Kim YC (ed.)). World Scientific, Singapore, pp. 261-286.

Nistor I, Goseberg N and Stolle J (2017) Tsunami-driven debris motion and loads: a critical review. Frontiers in Built Environment - Earthquake Engineering, 19 January, https://doi.org/10.3389/fbuil.2017.00002

NPAJ (National Police Agency of Japan) (2017) Great East Japan Earthquake Damage Report. NPAJ, Tokyo, Japan (in Japanese). See https://www.npa. go.jp/news/other/earthquake2011/index.html (accessed 24/04/2018).

Okada T, Sugano T, Ishikawa T et al. (2004) Structural design method of buildings for tsunami resistance - no. 2: design method (a draft). The Building Letter 2004(11): 1-8 (in Japanese).

Petrone C, Rossetto T and Goda K (2017) Fragility assessment of a RC structure under tsunami actions via nonlinear static and dynamic analyses. Engineering Structures 136: 36-53.

Pringgana G, Cunningham LS and Rogers BD (2016) Modelling of tsunamiinduced bore and structure interaction. Proceedings of the Institution of Civil Engineers - Engineering and Computational Mechanics 169(3): 109-125, https://doi.org/10.1680/jencm.15.00020.

Qi ZX, Eames I and Johnson ER (2014) Force acting on a square cylinder fixed in a free-surface channel flow. Journal of Fluid Mechanics 756 : 716-727, https://doi.org/10.1017/jfm.2014.455.

Raby A, Macabuag J, Pomonis A, Wilkinson S and Rossetto T (2015) Implications of the 2011 Great East Japan Tsunami on sea defence design. International Journal of Disaster Risk Reduction 14(4): 332-346, https://doi.org/10.1016/j.ijdrr.2015.08.009.

Robertson IN, Paczkowski K, Riggs HR and Mohamed A (2011) Tsunami bore forces on walls. In ASME 2011 30th International Conference on Ocean, Offshore and Arctic Engineering. Volume 1: Offshore Technology; Polar and Arctic Sciences and Technology. American Society of Mechanical Engineers, New York, NY, USA, paper OMAE2011-49487.

Robertson I, Riggs R and Chock G (2013) Development of Tsunami Design Provisions Webinar. Network for Earthquake Engineering Simulation (NEES), Purdue University, West Lafayette, IN, USA. See https:// datacenterhub.org/resources/6677/about (accessed 24/04/2018).

Rossetto T, Allsop W, Charvet I and Robinson DI (2011). Physical modelling of tsunami using a new pneumatic wave generator. Coastal Engineering 58(6): 517-527, https://doi.org/10.1016/j.coastaleng.2011.01.012.

Scott MH and Mason HB (2017) Constant-ductility response spectra for sequential earthquake and tsunami loading. Earthquake Engineering \& Structural Dynamics 46(9): 1549-1554, https://doi.org/10.1002/ eqe. 2871

Shibayama T, Esteban M, Nistor I et al. (2013) Classification of tsunami and evacuation areas. Natural Hazards 67(2): 365-386, https://doi. org/10.1007/s11069-013-0567-4

Thio HK, Somerville P and Polet J (2012) Probabilistic tsunami hazard analysis. 15th World Conference on Earthquake Engineering, Lisbon, Portugal.

Wei Y, Titov V, Thio HK, and Chock G (2014) Creation of probabilistic tsunami design zone. Proceedings of the 2013 NTHMP Summer MES/ MMS Subcommittee Meetings and Workshop. National Tsunami Hazard Mitigation Program (NTHMP), National Oceanic and Atmospheric Administration (NOAA), Silver Spring, MD, USA. See http://nws.weather. gov/nthmp/2013mesmms/abstracts/Wei.pdf (accessed 24/04/2018).

Yeh H, Robertson I and Preuss J (2005) Development of Design Guidelines for Structures that Serve as Tsunami Vertical Evacuation Sites. Division of Geology and Earth Resources, Washington Department of Natural Resources, Olympia, WA, USA. See http://nctr.pmel.noaa.gov/tsu400/ documents/Course_3_Day_3/Session_8/ofr05-4.pdf (accessed 24/04/2018) 